\title{
Pollinator behaviour in cultivated and wild Arctic Bramble (Rubus arcticus L.)
}

\author{
JAAKKO KANGASJÄRVI \& JARI OKSANEN \\ J. Kangasjärvi, Botanical Garden, University of Kuopio, SF-70211 Kuopio, Finland. \\ Present address: Department of Agronomy and Plant Genetics, University of Minnesota, \\ St. Paul, MN 55108, U.S.A. \\ J. Oksanen, Ecological Laboratory, Department of Environment, University of Kuopio, \\ SF-70211 Kuopio, Finland.
}

\begin{abstract}
Arctic bramble (Rubus arcticus) is a clonally growing, insect-pollinated, selfincompatible plant which is cultivated for its berries. In field studies of cultivated and natural stands it was observed that the pollinators (bumble bees and honey bees) foraged optimally, i.e., flight was towards the nearest flower. Therefore, in cultivation the plants should be planted so that the nearest neighbours belong to different clones. In general, the pollinators preferred white clover (Trifolium repens), growing as a weed, and cultivated strawberry as opposed to the arctic bramble. These plants appeared to be severe competitors for the pollinators, and care should therefore be taken to reduce their influence.
\end{abstract}

Index words: Rubus arcticus, Pollination, Optimal foraging, Fruit yield

\section{Introduction}

The European arctic bramble (Rubus arcticus subsp. arcticus), a native to northern Eurasia, produces berries which are highly esteemed for their aroma. In Finland, berries gathered from the wild are mainly used for the production of liqueurs. During the past few decades there has been a downward trend in the yields of berries, which have also been highly variable from year to year. Therefore attempts have been made to introduce the arctic bramble into cultivation.

At the beginning of this century, the arctic bramble grew commonly on abandoned slashand-burn (swidden) cultivations, preferring mesic sites (Koskimies 1930). Now the main habitats are roadsides and the sides of ditches. As arctic bramble clones spread effectively, one individual can cover a wide area (TАMMI- 
SOLA 1981). It is self-incompatible (TAMmisoLA \& RYYNÄNEN 1970) and requires pollination by large insects, such as honey bees and bumble bees (RYynänen 1973, HirRsalmi 1975).

Clones selected from nature ('Mespi' and 'Mesma'; RYYNÄNEN 1972) and a clone selected from their hybrid progeny ('Pima'; RYY. NÄNEN \& DALMAN 1983) are used in cultivation. Normally two clones are planted in the field; on the basis of recommendations (RYY. NÄNEN 1972, 1973, RyYnÄnEn \& Dalman 1983), each clone is planted in a row. For the two commonly available clones ('Pima' and 'Mespi') it is recommended that two rows of the better berry producer ('Pima') be planted so as to alternate with one row of the other clone.

The berry production of the arctic bramble is limited due to the lack of pollinators (HIIRSALMI 1975). The main pollinators, bumble bees (Bombus spp.) and honey bees (Apis mellifera), are selective and fairly true visitors. On the other hand, the optimal foraging theory predicts that the pollinator selects the plant species which gives maximum benefits at minimum costs (cf. Richards 1986). Moreover, in foraging a flower patch, the forager should leave the patch as soon as the energy used in foraging exceeds the gain (cf. Cibula and Zimmerman 1987). On leaving the patch the forager should select the nearest and most profitable patch (Heinrich 1979, ZimMERMAN 1982). If patches are equal as to their available resources, the nearest patch should be selected.

For this paper we studied the movement patterns of the foraging honey bees and bumble bees in the wild and cultivated arctic bramble. The consequences of the observations are discussed with respect to pollination and berry production.

\section{Material and methods}

An arctic bramble cultivation site in Karttula $\left(62^{\circ} 59^{\prime} \mathrm{N}, 26^{\circ} 57^{\prime} \mathrm{E}\right)$ consisting of two separate fields was studied in the summer of
1987. The older field was established in 1984 and had given yield before the study year; the younger field A was established in 1987. Contrary to the usual recommendations the fields contained the clones 'Pima' and 'Mespi' in equal proportions alternating in each row, so that the nearest neighbour was always a different clone. The distance between the rows was 70 to $90 \mathrm{~cm}$, that between the plants in a row being $30 \mathrm{~cm}$, and the area of the fields was ca. $200 \mathrm{~m}^{2}$. The rows were covered by dark plastic sheets with holes cut for the plants. The plastic prevented horizontal spread of the plants and resulted in distinct patches of growth. In the older field, where flowering was abundant, the flowers formed a nearly continuous canopy above the shoots. Common weeds, most notably white clover (Trifolium repens), were growing between rows that were not covered by the plastic. There was a honey bee hive on the farm.

Plots of $9 \mathrm{~m}^{2}$ and $16 \mathrm{~m}^{2}$ were marked out on the old and young fields, respectively, and the locations of the plants in each plot were mapped. The distances between the plants were estimated from the map. During the observation period ( 19 days between June 20 and July 20), every honey bee or bumble bee (later collectively called bees) visiting flowers of the bramble was followed in the plot, and the plants and flowers visited were recorded. In this study bumble bees were not identified as to the species level.

The movement patterns of bees were also recorded at two natural sites in Karttula $\left(62^{\circ} 53^{\prime} \mathrm{N}, 27^{\circ} 12^{\prime} \mathrm{E}\right.$ and $62^{\circ} 51^{\prime} \mathrm{N}$, $\left.27^{\circ} 03^{\prime} \mathrm{E}\right)$. At both sites the plants were growing in patches which covered appr. 15 to $20 \mathrm{~m}^{2}$. The sites were known by the local people to have produced abundant harvests of berries in earlier years. Arctic brambles were mapped and the movements of the pollinators were recorded similarly to the procedure followed in the cultivation.

During the flowering period of white clover, the flower preferences of the bees for clover and bramble were studied (three days between July 15 and 20). Two fields were studied: the 
old field was the same as described earlier, and the younger field $\mathrm{B}$ was at another cultivation site $\left(62^{\circ} 53^{\prime} \mathrm{N}, 27^{\circ} 12^{\prime} \mathrm{E}\right)$. Three rows of bramble were planted adjacent to eight rows of strawberry. The area of the field was ca. $150 \mathrm{~m}^{2}$, the distance between the rows being $120 \mathrm{~cm}$. Here the pollinator preference for strawberry was also recorded. In these obser-

Table 1. Abundance of pollinators in the cultivated field and in the wild stand.

\begin{tabular}{lcccrrrr}
\hline \multirow{2}{*}{ Site } & \multirow{2}{*}{$\begin{array}{c}\text { Hours } \\
\text { observed }\end{array}$} & \multicolumn{2}{c}{ Bumble bees } & & \multicolumn{2}{c}{ Honey bees } \\
\cline { 7 - 8 } \cline { 6 - 7 } \cline { 6 - 7 } & & total & per hour & & total & per hour \\
\hline Field & 57 & 44 & 0.77 & & 519 & 9.11 \\
Wild & 33 & 25 & 0.76 & & 1 & 0.03 \\
\hline
\end{tabular}

Table 2. Flight types of the cultivated arctic bramble as averaged for single pollinator visits within the observation plot.

\begin{tabular}{lccc}
\hline Flight type & $\begin{array}{c}\text { Average } \\
\text { number per } \\
\text { pollinator }\end{array}$ & $\begin{array}{c}\text { Standard } \\
\text { deviation }\end{array}$ & $\begin{array}{c}\text { Proportional } \\
\text { frequency } \\
(\%)\end{array}$ \\
\hline Within plant & 15.12 & 8.42 & 62.1 \\
Between plants & 8.29 & 3.97 & 34.1 \\
Between rows & 0.91 & 0.98 & 3.7 \\
Over row & 0.03 & 0.16 & 0.1 \\
\hline Total & 24.34 & 11.87 & 100.0 \\
\hline
\end{tabular}

vations the whole field, and not only the plot, was observed.

The summer of 1987 was rainy and cool. Meteorological data for Kuopio airport $\left(63^{\circ}\right.$ $01^{\prime} \mathrm{N}, 27^{\circ} 48^{\prime} \mathrm{E}$ ) are (averages for 19611975 in parentheses): precipitation in June $65.5 \mathrm{~mm}$ (37.0 mm), July $82.1 \mathrm{~mm}(30.3 \mathrm{~mm})$, average temperature in June $13.6^{\circ} \mathrm{C}\left(14.9^{\circ} \mathrm{C}\right)$, July $15.1^{\circ} \mathrm{C}\left(16.8^{\circ} \mathrm{C}\right)$.

\section{Results}

Bumble bees are native to the area, and their abundance in the brambles seemed to be remarkably similar when the natural and cultivated sites were compared (Table 1). The domestic honey bees were much more abundant in the cultivation (Table 1) and, evidently, they were the main pollinators in the field. The rainy and cool summer must have decreased both the activity and even the numbers of the pollinators.

Most of the flights were within a single plant, i.e., the pollinator tended to move between adjacent flowers (Table 2). The plants were located so that the inter-plant distance within the row was much smaller than the inter-row distance. Consequently, when the pollinator changed plant, it usually selected the neighbour in the same row (Table 2), as

Table 3. Distribution of flight distances (in \%) within the plot in the two cultivations and in a wild stand.

\begin{tabular}{lcccccc}
\hline & \multicolumn{5}{c}{ Flying distance $(\mathrm{cm})$} \\
\cline { 2 - 7 } & $0-4.9$ & $5-9.9$ & $10-49.9$ & $50-99.9$ & $\geq 100$ & $\mathrm{~N}$ \\
\hline Old field & 66.1 & 14.6 & 6.7 & 9.1 & 3.5 & 342 \\
Young field A & 65.0 & 15.4 & 8.8 & 7.9 & 2.9 & 240 \\
Wild & 69.5 & 21.7 & 8.4 & 0.5 & 0.0 & 203 \\
\hline
\end{tabular}

Table 4. Visiting preferences between some plants in cultivated arctic bramble ('-' data not available).

\begin{tabular}{|c|c|c|c|c|c|c|}
\hline \multirow[t]{3}{*}{ Site } & \multicolumn{6}{|c|}{ Plant selected by pollinators } \\
\hline & \multicolumn{2}{|c|}{ Arctic bramble } & \multicolumn{2}{|c|}{ White clover } & \multicolumn{2}{|c|}{ Strawberry } \\
\hline & visits & $\%$ & visits & $\%$ & visits & $\%$ \\
\hline Old field & 166 & 14.9 & 951 & 85.1 & - & - \\
\hline Young field B & 0 & 0.0 & 968 & 66.7 & 484 & 33.3 \\
\hline
\end{tabular}


predicted by the optimal foraging theory. Most of the flights were short, and only ca. $3 \%$ of the flights were longer than $100 \mathrm{~cm}$ (Table 3).

In the young field the arctic bramble flowering was fairly scarce and during the research period no visits were made by the pollinators, although at the same time strawberry and particularly clover were popular (Table 4). In the old field the bramble flowered profusely, but the pollinators still preferred the white clover growing as a weed between the rows.

\section{Discussion}

Several previous studies have found that the behaviour predicted by the optimal foraging theory holds for bumble bees and honey bees (e.g. Zimmerman 1979, 1982), as was also confirmed in this study. Because the arctic brambles are spread clonally, self-incompatible and insect-pollinated, the pollinator movement patterns have a great influence on the production of seeds and berries (cf. HANDEL 1985, TAMmisola 1981, 1986).

The study of plant pollination can be fraught with methodological problems (RICHARDS 1986). We only observed pollinator movements, and not pollen movement, deposition or action. Therefore, it would be impossible to say exactly when pollination occurred. However, there were only two self-incompatible clones which were in a regular geometric pattern in the field. Since we know that pollination can occur by the transfer of pollen between these two clones, we can draw some conclusions on the efficacy of the pollinators.

Several pollen grains are needed for the development of full-sized berry (one for each seed). If the pollinator alights on a flower from a different clone, it will be capable of depositing several effective pollen grains during a single visit (cf. YевоAн Gyan and WooDELL 1987). However, the turnover of pollen seems to be quite rapid: most of the old pollen will be deposited in the first few flowers visited (Thomson 1986), and as the bee visits more flowers of the same clone, the old pollen will be replaced by that of the new clone (HANDEL 1985). Pollinators usually alight on several (ca. 15) flowers of a single plant, and consequently, only the first few flowers visited receive effective pollen.

A great majority of the flights are to the nearest neighbour (cf. ZimMERMAN 1979, 1982). Plants of the same clone are not capable of being pollinated from pollen transferred by the bee. The practice of planting a single clone in each row, although economical to establish, can notably decrease the yields: a period of effective pollination commences only when the pollinator changes rows to the alternate clone. If the recommended ratio of $1: 2$ for plants were followed, only $2 / 3$ of the changes to the adjacent row would be accompanied by a change in the clone.

The summer of 1987 was cool and rainy, which decreased the activity of the pollinators and also probably reduced their numbers (particularly the native bumble bees). If there are abundant pollinators, the adverse effects of the planting pattern should become negligible. Moreover, when there are many pollinators they are more likely to meet each other and so possibly fly longer distances to avoid conflicts. In general, hermahproditic plants produce many more flowers than fruit (SUTHERLand 1987, cf. Stanton and Preston 1988). Arctic bramble generally produces flowers in excess, but still the yield seems to be limited by the number of pollinators, as was shown by the introduction of bee hives to cultivations (Hirrsalmi 1975). Therefore, even in favourable conditions the berry yields could probably be increased by adapting a planting pattern where neighbouring plants belong to different clones.

Competition between plants for pollinators has been shown to occur (FrEE 1968, WASER 1978, Campbell 1985, Richards 1986; cf. FEINSINGER 1987). It seems that bees clearly prefer white clover, and possibly also strawberry, to arctic bramble. It has been shown that dandelions (Taraxacum) can decrease apple yields because of competition for pollinators (FrEE 1968). Therefore it would be 
reasonable to try to improve the arctic bramble's ability to compete by cultivating it away from other flowering field plants attractive to the pollinators and by controlling the flowering weeds. However, the main flowering of white clover is later than that of the bramble, so the competitor can only have an effect on the later yields, which are rather important in the arctic bramble. Moreover, observations from some other self-incompatible insectpollinated plants indicate that a greater proportion of flowers produces berries in the later flowering period, since there are fewer flowers on one plant and insects change host

\section{References}

CAmprell, D.R. 1985. Pollen and gene dispersal: The influences of competition for pollination. Evolution 39: $418-431$.

Cibula, D.A. \& Zimmerman, M. 1987. Bumblebee foraging behavior: Changes in departure decisions as a function of experimental nectar manipulations. Amer. Midl. Nat. 117: 386-394.

Feinsinger, P. 1987. Effects of plant species on each other's pollination: Is community structure influenced? Trends Ecol. Evol. 2: 123-126.

FreE, D.B. 1968. Dandelion as a competitor to fruit trees for bee visits. J. Appl. Ecol. 5: 169-178.

HANDEL, S.N. 1985. The intrusion of clonal growth patterns on plant breeding systems. Amer. Nat. 125: $367-384$.

HeinRICH, B. 1979. Resource heterogeneity and patterns of movement in foraging bumblebees. Oecologia (Berl.) 40: 235-245.

Hırsalmi, H. 1975. Pölyttäjien, ilman kosteuden ja lămpötilan merkityksestä mesimarjan marjonnalle. Maaseudun tulevaisuus, Koetoiminta ja kảytăntő $1 / 1975$.

Koskımies, A.E. 1930. Mesimarjasta (Rubus arcticus) Pohjois-Karjalassa. Luonnon ystävă 35: 47-49.

Richards, A.J. 1986. Plant breeding systems. George Allen \& Unwin, Boston. 529 pp.

RYYNANEN, A. 1972. Arctic bramble (Rubus arcticus L.), a new cultivated plant. Ann. Agric. Fenn. 11: 170-173.

RYYNÁNEN, A. 1973. Rubus arcticus L. and its cultivation. Ann. Agric. Fenn. 12: 1-76.

RYYnĀnen, A. \& Dalman P. 1983. A new variety of aretic bramble 'Pima'. Ann. Agric. Fenn. 22: 1-7.

Stanton, M.L. \& Preston, R.E. 1988. A qualitative model for evaluating the effects of flower attractive- more often (Zimmerman 1987). At present, we cannot assess the importance of white clover with respect to bramble yields, but the results indicate that there is reasons to attempt reducing its effects.

Acknowledgements. This study was financially supported by the National Board of Agriculture, Liqueur Manufacturer Lignell \& Piispanen Oy, the Municipality of Karttula and Kuopio Provincial Government. We are indebted to Mr Jari Spoof for skilful field assistance, to the farmers for their co-operation, to Prof. Lauri Kärenlampi, Mr Jarmo Holopainen and Dr Irma Suhonen for critical comments on the manuscript, and to Mr Robin Sen for revising the language.

ness on male and female fitness in plants. Amer. J. Bot. 75: 540-544.

Sutherland, S. 1987. Why hermaphroditic plants produce many more flowers than fruits: Experimental tests with Agave mckelveyana. Evolution 41: 750759.

TAmmisola, J. 1981. Principles of genetic sampling and conservation in perennial species. A case study in arctic bramble (Rubus arcticus). In: Seed Regeneration in Cross-pollinated Species (Eds E. Porceddu \& G. Jenkins), pp. 165-189. A.A. Belkema, Rotterdam.

TAmmisola, J. 1986. Populations in clonal plants. J. Agric. Sci. Finland 58: 239-276.

TAMmISOLA, J. \& RYYNĀNEN, A. 1970. Incompatibility in Rubus arcticus L. Hereditas 66: 269-278.

Thомson, J.D. 1986. Pollen transport and deposition by bumble bees in Erythronium: Influences of floral nectar and bee grooming. J. Ecol. 74: 329-341.

WASER, N.M. 1978. Interspecific pollen transfer and competition between co-occurring plant species. Oecologia (Berl.) 36: 223-236.

Yeboah Gran, K. \& Woodell, S.R.J. 1987. Analysis of insect pollen loads and pollination efficiency of some common insect visitors of four species of woody Rosaceae. Funct. Ecol. 1: 269-274.

Zimmerman, M. 1979. Optimal foraging: A case of random movement. Oecologia (Berl.) 43: 261-267.

Zimmerman, M. 1982. Optimal foraging: Random movement by pollen collecting bumble bees. Oecologia (Berl.) 52: 104-108.

Zimmerman, M. 1987. Reproduction in Polemonium: factors influencing outbreeding potential. Oecologia (Berl.) 72: 624-632.

Ms received 


\section{SELOSTUS}

\section{Pölyttäjien käyttäytyminen mesimarjassa}

\section{Jaakko Kangasjärvi ja Jari Oksanen}

\section{Kuopion Yliopisto}

Mesimarja on klonaalisesti leviävä itsesteriili kasvi. Sitả viljelläăn yleisesti siten, ettả samalla viljelmällä kasvatetaan kahta lajiketta rinnan. Nämă pystyvăt pölyttämaaăn toisensa mutteivät itseäăn. Tässä tutkimuksessa on tarkasteltu pölyttäjăhyönteisten (kesymehiläisten ja kimalaisten) käyttäytymistă Karttulassa sijaitsevilla viljelmillä, joissa mesimarjaa kasvatetaan muovikatteessa riveihin istutettuina. Pölyttäjien havaittiin pääasiallisesti lentảvăn pitkin riviä. Tăllä tavoin ne pystyivät minimoimaan lentomatkansa. Samaten tutkituissa luonnonkannoissa pö- lyttaajăt yleensä lensivăt lähimpaaăn naapurikasviin. Mikäli, kuten tavallista on, samassa rivissä on vain yhtả lajiketta, on pölytysteho todennăköisesti huono. Lajikkeet olisi siksi suotavaa istuttaa riviin vuorotellen. Lisăksi havaittiin, ettă pölyttảjăt suosivat sekă rivien väleissă rikkaruohona kasvavaa valkoapilaa ettă naapurustossa viljeltyã mansikkaa. Kumpikaan ei pystynyt houkuttelemaan mesimarjaviljelmälle lisaaă pölyttaajiă vaan năytti kilpailevan samoista pölyttäjistä mesimarjan kanssa, joten myös pölytyskilpailun vähentäminen lienee aiheellista. 